2020-02

Selfperceived preparedness of undergraduate dental students in dental public universities in Malaysia: A national study

Mat Yudin, Z

http://hdl.handle.net/10026.1/15129

10.1111/eje. 12480

European Journal of Dental Education

Wiley

All content in PEARL is protected by copyright law. Author manuscripts are made available in accordance with publisher policies. Please cite only the published version using the details provided on the item record or document. In the absence of an open licence (e.g. Creative Commons), permissions for further reuse of content should be sought from the publisher or author. 
Self-Perceived Preparedness of Undergraduate Dental Students In Dental Public Universities In Malaysia: A National Study

Running Tittle: Dental Students Practice Preparedness In Malaysia

Keywords: dental; preparedness; students; undergraduates

(i) Zainab Mat Yudin@Badrin, School Of Dental Sciences, Universiti Sains Malaysia, Kampus Kesihatan, 16150 Kubang Kerian, Kelantan.

(ii) Kamran Ali, University of Plymouth Peninsula Schools of Medicine \& Dentistry, Plymouth, United Kingdom

(iii) Wan Muhamad Amir Wan Ahmad, School Of Dental Sciences, Universiti Sains Malaysia, Kampus Kesihatan, 16150 Kubang Kerian, Kelantan.

(iv) Anisa Ahmad, 
School Of Medical Sciences, Universiti Sains Malaysia, Kampus Kesihatan, 16150 Kubang Kerian, Kelantan.

(v) Mohd. Fadhli Khamis, School Of Dental Sciences, Universiti Sains Malaysia, Kampus Kesihatan, 16150 Kubang Kerian, Kelantan.

(vi) Nur 'Aliya Brian Graville Monteiro@lbrahim, School Of Dental Sciences, Universiti Sains Malaysia, Kampus Kesihatan, 16150 Kubang Kerian, Kelantan.

(vii) Zeti Adura Che Ab. Aziz, Faculty of Dentistry, Universiti Malaya, 50603 Kuala Lumpur.

(viii) Roslan Saub, Faculty of Dentistry, Universiti Malaya, 50603 Kuala Lumpur.

(ix) Tanti Irawati Rosli, Faculty of Dentistry, Universiti Kebangsaan Malaysia, 50300 Kuala Lumpur.

(x) Aspalilah Alias, Faculty of Dentistry, Universiti Sains Islam Malaysia, 55100 Kuala Lumpur.

(xi) Nor Faharina Abdul Hamid, Faculty of Dentistry, Mara University Institute Of Technology (UiTM), 47000 Sungai Buloh, Selangor.

(xii) Nor Asilah Harun, 
Kulliyyah of Dentistry, International Islamic University Malaysia (IIUM), 25200 Kuantan, Pahang.

\section{Corresponding author :}

Dr Zainab Mat Yudin, School of Dental Sciences, Health Campus, Universiti Sains Malaysia (USM), 16150 Kubang Kerian, Kelantan, Malaysia.

\section{Email: drzainab@usm.my.}

Telephone number: $+60097671187 / 01110622974$

\section{Acknowledgements}

The authors would like to express their gratitude to Universiti Sains Malaysia for providing research funding (Grant no.304/PPSG/6315039), School of Dental Sciences, Universiti Sains Malaysia).

\section{Competing interests}

We declare there is no financial and personal relationship with other people or organizations that could inappropriately influence the research. 


\title{
Self-Perceived Preparedness of Undergraduate Dental Students In Dental Public Universities In Malaysia: A National Study
}

\author{
Abstract \\ Aims: To evaluate the self-perceived preparedness of final year dental undergraduate \\ students in dental public universities in Malaysia. \\ Methods: Final year dental undergraduate students from six dental public universities in \\ Malaysia were invited to participate in an online study using a validated Dental \\ Undergraduates Preparedness Assessment Scale DU-PAS.
}

Results: In total about 245 students responded to the online questionnaire yielding a response rate of $83.05 \%$. The age range of the respondents was 23 to 29 years with a mean age of 24.36 (SD 0.797). The total score obtained by the respondents were ranged from 48 to 100 with a mean score of 79.56 (SD 13.495). Weaknesses were reported in several clinical skills, cognitive and behavioural attributes.

Conclusions: The preparedness of undergraduate students at six dental institutions in Malaysia was comparable to students from developed countries. The dental undergraduate preparedness assessment scale is a useful tool and dental institutions may be used for self-assessment as well as to obtain feedback from the supervisors. 


\section{Introduction}

The changing healthcare needs in the modern society warrant that the students in healthcare professions are prepared adequately to meet the challenges of delivering predictable and effective prevention and management of disease (1). The process of developing the capacity for independent practice in health-care professions typically extends well beyond the temporal confines of undergraduate university education (2). Preparedness of graduates in healthcare education is a topic of fundamental significance. Research in undergraduate medical education involving pedagogy, clinical training, curriculum development and assessment methods is ultimately aimed at informing the stakeholders how best to prepare the graduates for their future careers (36)

Dental graduates face a multitude of challenges in order to prepare themselves for a smooth transition from a dental school into practice and preparedness of dental graduates is a subject of immense interest worldwide (7). Following the Bologna Declaration, the last two decades have witnessed a strong trend towards Europeanization of higher education (8). The European initiatives have adopted a more integrated approach of developing unified clusters of knowledge, skills and attitudes that facilitate an introduction into a field of study and subsequent transition into work environments. The Association for Dental Education in Europe (ADEE) has developed a curriculum framework for undergraduate dental education which reflects the best academic practice for undergraduate dental education (9).

As one of the developing countries in Asia, Malaysia started its first dental programme in 1972 at the University of Malaya and over the next two decades, additional dental programmes were initiated at other universities in Malaysia. Presently, undergraduate dental programmes are offered at six public sector and seven private institutions in Malaysia (10). Preparing students to work independently in a dental practice setting following graduation is one of the primary goals of dental education. Undergraduate dental education is aimed at producing graduates who are biologically oriented, technically competent, socially sensitive dental practitioners, who adhere to the 
standards of professional conduct and ethics, and who can function effectively as a member of the nation's healthcare delivery system (11). Before starting a career as a dental practitioner, graduate students are expected to be competent in providing quality holistic patient care and should also be prepared to adapt with the needs of the society and be competent in the practice management (12). Dental students are expected to develop a range of psychomotor and affective skills during their undergraduate education. However, evidence from the literature shows that whilst most of dental students are confident and prepared to carry out simple operative procedures, they may not be adequately prepared to carry out more complex clinical procedures such as endodontics on multi-rooted teeth or surgical extractions (13-14).

The aim of this national study was to assess the self-reported preparedness of final year dental students at all six public sector universities in Malaysia.

\section{Methods}

\section{Study Design and Setting}

It was a cross-sectional study among final year dental undergraduate students in dental public universities in Malaysia using an online questionnaire.

\section{Research Instrument}

The study was based on the Dental Undergraduates Preparedness Assessment Scale DU-PAS which is a valid and reliable tool to measure a broad range of skills and attributes expected from dental students at the time of graduation (15). Part A of the scale consists of 24 items which focus on clinical skills and are scored on a three-point scale ranging from No experience (0); With verbal and / or practical input from a colleague (1); and On my own, Independently (2). Part B consists of 26 items related to cognitive and behavioural attributes scored on a three-point scale ranging from No experience (0); Mostly (1); and Always (2). The total score on DU PAS may range from $0-100$. 


\section{Data Collection}

The study was administered online and invitation to the participants were accompanied by a participant information sheet summarizing the aims of the study. Consent of the participants were obtained before collecting their responses. The participants were given four weeks to respond to the questionnaire. A reminder was sent after three weeks after they received the initial online questionnaire. No further reminders were sent.

\section{Ethics Approval}

Ethics approval to conduct the study was obtained from the research ethics committee of Universiti Sans Malaysia (USM/JEPem/18010022).

\section{Data Analysis}

Data entry and analysis was done using SPSS version 24. Data collection and analysis were completed in approximately 12 months. 


\section{Results}

The response rate for this study was $83.05 \%$ which involved 245 undergraduate dental students from six public dental universities in Malaysia. The age of the respondents were in the range of 23 to 29 years old with the mean age of 24.36 (SD 0.797). Majority of the respondents were female (72.7\%), unmarried (94.7\%) and Malay ethnic $(74.3 \%)$. The sociodemographic characteristics of the respondents are shown in Table 1. The total score obtained by the respondents were ranged from 48 to 100 with a mean score of 79.56 (SD13.495) as shown in Table 2.

Part A of the scale comprises the clinical skills experience the respondents encountered during undergraduate dental education programme. The mean percentage scores for Part A are shown in Table 3. The items are ordered by the "independently" performing the procedures in an ascending order. Almost all the respondents had an experience in performing the procedures or experiencing the related skills either with help or independently. Less than $65 \%$ of respondents were able to independently perform procedures for the items A7 (Assess treatment needs for orthodontics); A8 (Comprehensive treatment planning); A9 (Discuss treatment options); A13 (Prescribe drugs); A21 (Provide crowns); A22 (Provide mechanically sound partial dentures); and A20 (Endodontics on multi-rooted teeth).

Part B of the scale evaluates cognitive and behavioural attributes. The mean percentage scores for Part B are shown in Table 4 ordered by the "Always" in an ascending order. Majority of the participants reported limited experience in attributes related to items B25 (Manage patient expectations); B32 (Scientific knowledge); B33 (Evaluate dental materials); B34 (Interpret research results); and B42 (Manage children). Lack of experience was observed in several other items and the most remarkable amongst these items were B30 (Referral of suspected oral cancer); B35 (Using an evidence-informed approach) and B41 (Managing anxious patients). 


\section{Discussion}

This is the first study on preparedness of dental students to be conducted at public dental institutions in Malaysia. The results of this study show the dental graduates of Malaysia are well prepared and comparable to graduates from developed countries. The mean total score of the respondents in this study was 79.56 (SD13.49). Previous studies in Pakistan (16) and United Kingdom (17) revealed mean score of 65.60 and 74.0 respectively. Our data also highlights areas of weaknesses which require further education and training.

Regarding clinical skills, over $85 \%$ of the respondents reported competence in administering inferior dental nerve blocks, removing dental caries, obtaining a valid consent from patients, performing non-surgical periodontal treatment and undertaking bitewing radiographs. In contrast to the findings amongst Pakistani students, the undergraduate dental students which showed inadequate least experience in undertaking bitewing radiographs (16), our study shows that a vast majority of students in this study were able to undertake radiographs independently. This corroborates with the findings from dental students in the United Kingdom (17). Availability and good maintenance of radiographic equipment is important to ensure students have learning experience in doing such procedures.

Self-perceived preparedness was low in performing endodontic treatment on multi rooted, prescribing drugs to patients, assessing the treatment needs of patients requiring orthodontics and providing mechanically sound partial dentures. Endodontic treatment is challenging for undergraduate students and deficiencies in this skill have been reported widely $(13,14,18)$. Nevertheless, if the students are able to demonstrate competence in performing simple endodontics on single rooted teeth as shown by the results of this study, they may be able to develop their skills in multi-rooted endodontics with further experience (19). Improving the learning experience by increasing clinical hours for independent practice may be an effective strategy to enhance clinical skills of the students during undergraduate education (12). 
About $52 \%$ of respondents needed advice for drug prescriptions. Similar findings are reported in previous studies $(20,21)$. Prescription writing requires an understanding of patient's medical history, diagnosis and knowledge of relevant drugs to allow safe administration. Prescribing medication to patient is a core skill in clinical dental practice and dental educators in Malaysia need to revisit the teaching of undergraduate students in this area to ensure that the students get regular opportunities to write drug prescriptions for their patients under supervision of qualified dental staff. Implementing the World Health Organisation (WHO) Guide on Good Prescribing may serve as a useful tool for the students to develop skills in drug prescription (22).

Most of the final year students had perceived themselves communicating well with colleagues, practising professionalism and had a good effort in improving themselves by being responsibility about their continuing professional development. Installing professionalism in practice is part of the important things that all health care workers need especially when dealing with colleagues, other staff and patients. Although the respondents in this study reported limited confidence in managing the patients' expectations, the students are able to provide opportunities for the patients to express their expectations from dental treatment. Further experience needs to be provided during the undergraduate education so that the students gain confidence in managing patients' expectations to improve patients' satisfaction with the treatment received and improve compliance.

Undergraduate education is aimed at providing the foundations to build and develop scientific knowledge and its application in clinical practice. Contemporary dental education emphasises on understanding the needs of society, critical thinking, and research skills in undergraduate dental curricula (23). Supporting the dental students to develop skills in using an evidence-based approach and its application in patient management is widely recognised. Results of this study shows the students in Malaysia lack confidence in this area and similar findings are reported elsewhere $(24,25)$. These findings underscore the need to enhance education and training of undergraduate students in evidence-based dentistry. Almost 30\% of the respondents did not have 
experience in recognition and referral of patients with suspected oral cancer. It is suggested that dental schools may be unable to provide a consistent experience in identification of oral cancer and precancerous lesions, often due to limited number of patients and / or insufficient staff training. This learning need may be best addressed by providing a structured exposure to cancer patients in specialist maxillofacial surgery departments (16).

\section{Conclusion}

This maiden national study at public dental institutions Malaysia provides useful insights into the strengths and weaknesses of the perceived preparedness of final year undergraduate students. Malaysian dental students perceived their preparedness to be adequate in most areas and their scores were comparable to those in developed countries. However, confidence and experience in some clinical skills; cognitive and behavioural attributes could be improved to facilitate their transition into independent dental practice after graduation. DU PAS may serve as a useful tool for the dental educators for a broad-based evaluation of the preparedness of their undergraduate students and inform future developments in curriculum design and teaching strategies 


\section{References}

1. Pershing S, Fuchs VR. Restructuring medical education to meet current and future health care needs. Acad Med. 2013;88(12):1798-801.

2. Peden-McAlpine C. Expert thinking in nursing practice: implications for supporting expertise. Nurs Health Sci. 1999;(2):131-7.

3. Miles S, Kellett J, Leinster SJ. Medical graduates' preparedness to practice: a comparison of undergraduate medical school training. BMC Med Educ. 2017;6;17(1):33.

4. Kellett J, Papageorgiou A, Cavenagh P, Salter C, Miles S, Leinster SJ. The preparedness of newly qualified doctors - Views of Foundation doctors and supervisors. Med Teach. 2015;37(10):949-54.

5. Monrouxe LV, Bullock A, Gormley G, Kaufhold K, Kelly N, Roberts CE, Mattick K, Rees C. New graduate doctors' preparedness for practice: a multistakeholder, multicentre narrative study. BMJ Open. 2018;29;(8):e023146.

6. Banneheke $H$, Nadarajah VD, Ramamurthy $S$, Sumera A, Ravindranath $S$, Jeevaratnam K, Efendie B, Chellamuthu L, Krishnappa P, Peterson R. Student preparedness characteristics important for clinical learning: perspectives of supervisors from medicine, pharmacy and nursing. BMC medical education. 2017;17(1):130.

7. Mohan M, Ravindran TKS. Conceptual Framework Explaining "Preparedness for Practice" of Dental Graduates: A Systematic Review. J Dent Educ. 2018;82(11):1194-1202.

8. Dobbins M, Knill C. Higher education policies in Central and Eastern Europe: convergence toward a common model? Governance. 2009;22(3):397-430.

9. Field JC, Cowpe JG, Walmsley AD. The Graduating European Dentist: A New Undergraduate Curriculum Framework. Eur J Dent Educ. 2017;21 Suppl 1:2-10.

10. Abu-Hassan MI. Dental education in Malaysia: journey towards excellence. Shah Alam, Malaysia: University Publication Centre. 2010.

11. Ministry of Health, Oral Health Program, History of Dentistry In Malaysia, Available at: http://ohd.moh.gov.my/v3/index.php/en/about-us/history-of-dentistry [Accessed April 2019] 
12. Manakil J, George R. Self-perceived work preparedness of the graduating dental students. Eur J Dent Educ. 2013;17(2):101-05

13. Gound TG, Sather JP, Kong TS, Makkawy HA, Marx DB. Graduating dental students' ability to produce quality root canal fillings using single- or multiple-cone obturation techniques. J Dent Educ. 2009;73(6):696-705.

14. Gilmour AS, Welply A, Cowpe JG, Bullock AD, Jones RJ. The undergraduate preparation of dentists: Confidence levels of final year dental students at the School of Dentistry in Cardiff. Br Dent J. 2016;221(6):349.

15. Ali K, Slade A, Kay EJ, Zahra D, Chatterjee A, Tredwin C. Application of Rasch analysis in the development and psychometric evaluation of dental undergraduates preparedness assessment scale. Eur J Dent Educ. 2017; 21(4):e135-41.

16. Ali K, Cockerill J, Zahra D, Qazi HS, Raja U, Ataullah K. Self-perceived preparedness of final year dental students in a developing country-A multiinstitution study. Eur J Dent Educ. 2018 ;22(4):e745-e750.

17. Ali K, Slade A, Kay E, Zahra D, Tredwin C. 2017, Preparedness of Undergraduate dental students in the United Kingdom: a national study. $\mathrm{Br}$ Dent J.;222(6):472-477.

18. Murray CM, Chandler NP. Undergraduate endodontic teaching in New Zealand: Students' experience, perceptions and self-confidence levels. Aust Endod J. 2014;40(3):116-22.

19. Qualtrough AJ. Undergraduate endodontic education: what are the challenges? Br Dent J. 2014;216(6):361.

20. Akram A, ZamZam R, Mohamad NB, Abdullah D, Meerah SM. An assessment of the prescribing skills of undergraduate dental students in Malaysia. J Dent Educ. 2012;76(11):1527-31.

21.Zadik Y, Levin L. Clinical decision making in restorative dentistry, endodontics, and antibiotic prescription. J Dent Educ. 2008; 72(1):81-6.

22. Jain A, Gupta D, Singh D, Garg Y, Saxena A, Chaudhary H, Singh A, Gupta RK. Knowledge regarding prescription of drugs among dental students: A descriptive study. J Bas Clin Pharm. 2015;7(1):12. 
23. Najafi NF, Asgari I. Effectiveness of a program on evidence-based dentistry in dental students. J Educ Health Promot. 2017;6.

24. Nieminen P, Virtanen Jl. Information retrieval, critical appraisal and knowledge of evidence-based dentistry among Finnish dental students. Eur J Dent Educ. 2017; 21(4):214-9.

25. Straub-Morarend CL, Wankiiri-Hale CR, Blanchette DR, Lanning SK, Bekhuis T, Smith BM, Brodie AJ, Oliveira DC, Handysides RA, Dawson DV, Spallek H. Evidence-based practice knowledge, perceptions, and behavior: a multiinstitutional, cross-sectional study of a population of US dental students. J Dent Educ. 2016; 80(4):430-8. 
Table 1: Demographic Characteristics of the Participants

\begin{tabular}{|c|c|c|c|c|}
\hline & & Mean (sd) & Frequency (n) & Percentage (\%) \\
\hline \multirow[t]{2}{*}{ Age } & & 24.36 & & \\
\hline & & $(0.797)$ & & \\
\hline \multicolumn{5}{|c|}{ Gender } \\
\hline & Female & & 178 & 72.7 \\
\hline & Male & & 67 & 27.3 \\
\hline \multicolumn{5}{|c|}{ Marital status } \\
\hline & Unmarried & & 232 & 94.7 \\
\hline & Married & & 13 & 5.3 \\
\hline \multicolumn{5}{|c|}{ Ethnicity } \\
\hline & Malay & & 182 & 74.3 \\
\hline & Chinese & & 55 & 22.4 \\
\hline & Indian & & 3 & 1.2 \\
\hline
\end{tabular}


Table 2: Total Score of the Participants

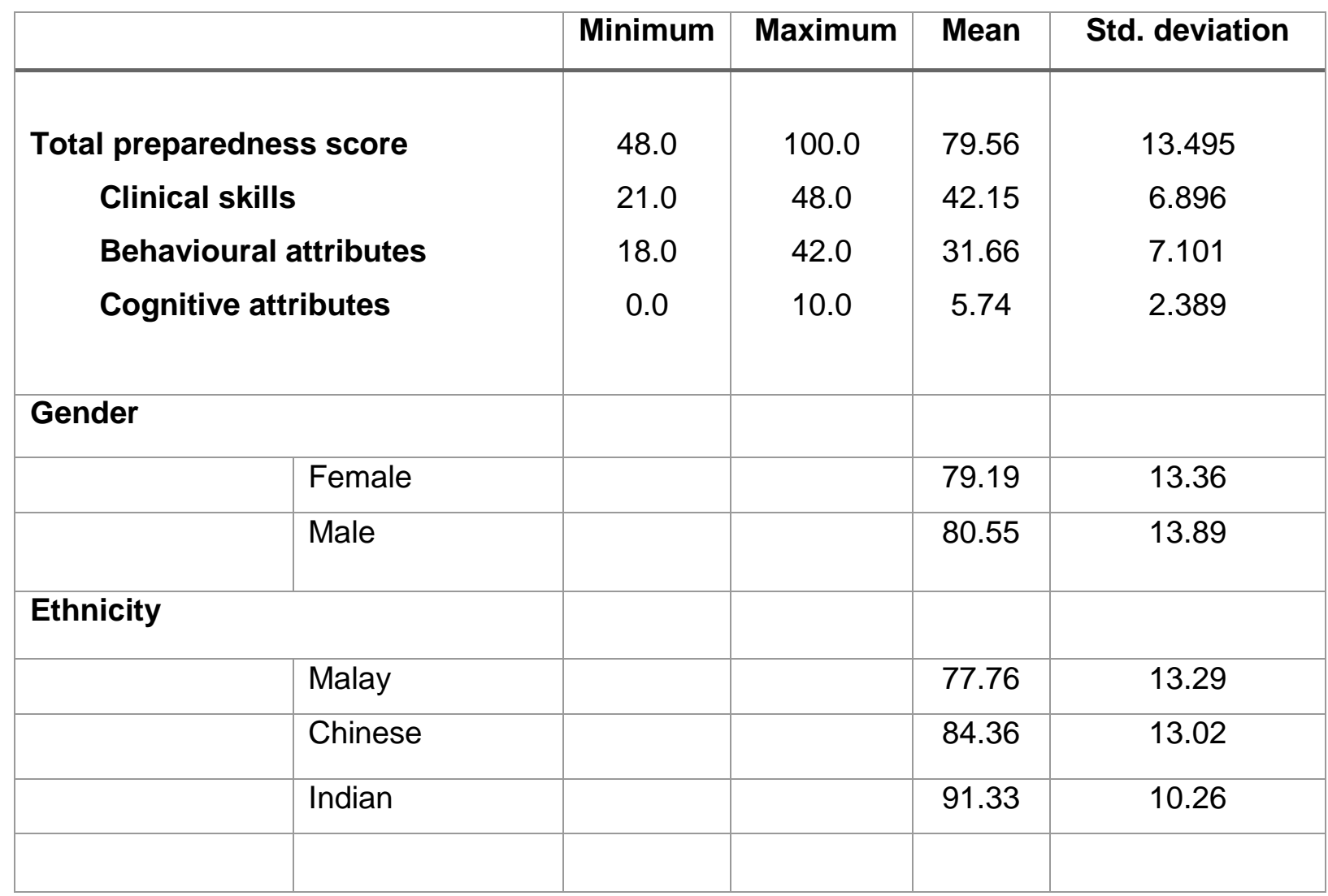


Table 3: Summary of Mean Percentage Scores for Part A

\begin{tabular}{|c|c|c|c|}
\hline Question & $\begin{array}{c}\text { No } \\
\text { experience } \\
(\%)\end{array}$ & $\begin{array}{l}\text { With } \\
\text { help } \\
(\%)\end{array}$ & $\begin{array}{c}\text { Independently } \\
(\%)\end{array}$ \\
\hline $\begin{array}{l}\text { A20I am able to perform endodontic treatment on multi } \\
\text { rooted teeth appropriately }\end{array}$ & 0.0 & 55.9 & 44.1 \\
\hline $\begin{array}{l}\text { A13 I am able to prescribe drugs to my patients } \\
\text { appropriately }\end{array}$ & 0.0 & 52.3 & 44.7 \\
\hline $\begin{array}{l}\text { A7 I am able to assess the treatment needs of patients } \\
\text { requiring orthodontics }\end{array}$ & 1.3 & 46.3 & 52.5 \\
\hline $\begin{array}{l}\text { A22 I am able to provide mechanically sound partial } \\
\text { dentures }\end{array}$ & 0.0 & 31.8 & 68.2 \\
\hline $\begin{array}{l}\text { A10I am able to explain the merits and demerits of various } \\
\text { treatment options to my patients }\end{array}$ & 0.4 & 29.5 & 70.1 \\
\hline $\begin{array}{l}\text { A21 I am able to provide crowns using principles of tooth } \\
\text { preservation }\end{array}$ & 0.0 & 28.7 & 71.3 \\
\hline $\begin{array}{l}\text { A8 I am able to formulate a comprehensive treatment } \\
\text { plan which addresses all treatment needs of my } \\
\text { patients }\end{array}$ & 0.0 & 28.2 & 71.8 \\
\hline $\begin{array}{l}\text { A9 I am able to provide a range of treatment options to } \\
\text { my patients based on their individual circumstances }\end{array}$ & 0.0 & 27.9 & 72.1 \\
\hline $\begin{array}{l}\text { A23 I am able to provide mechanically sound/safe and } \\
\text { functioning full dentures }\end{array}$ & 0.0 & 24.9 & 75.1 \\
\hline $\begin{array}{l}\text { A12 I am able to carry out patients' treatment sessions in } \\
\text { an appropriate order }\end{array}$ & 0.0 & 22.9 & 77.1 \\
\hline $\begin{array}{l}\text { A18I am able to restore teeth with amalgam fillings } \\
\text { appropriately }\end{array}$ & 0.4 & 21.7 & 77.9 \\
\hline $\begin{array}{l}\text { A2 I am able to undertake a comprehensive, clinical oral } \\
\text { examination }\end{array}$ & 0.0 & 19.2 & 80.8 \\
\hline $\begin{array}{l}\text { A24 I am able to undertake non-surgical tooth extractions } \\
\text { appropriately }\end{array}$ & 0.0 & 19.2 & 80.8 \\
\hline $\begin{array}{l}\text { A6 I am able to interpret common findings on dental } \\
\text { radiographs }\end{array}$ & 0.0 & 18.8 & 81.2 \\
\hline
\end{tabular}


A3 I am able to prescribe appropriate dental radiographs

$0.0 \quad 18.4 \quad 81.6$

A1 I am able to obtain a complete medical history from

$0.0 \quad 17.6 \quad 82.4$

my patients.

A19l am able to perform endodontic treatment on single

$0.0 \quad 17.6 \quad 82.4$

rooted teeth appropriately

A4 I am able to undertake periapical radiographs

$\begin{array}{lll}0.0 & 16.3 \quad 83.7\end{array}$

A17I am able to restore teeth with tooth coloured fillings

$0.0 \quad 15.1$

84.9 appropriately

A14I am able to administer inferior dental nerve blocks

0.0

13.5

86.5 effectively

A16I am able to remove dental caries effectively

0.0

13.1

86.9

A11 I am able to obtain a valid consent from my patients

0.0

11.8

88.2 prior to undertaking any treatment.

A15I am able to perform non-surgical periodontal

$\begin{array}{lll}0.4 & 10.3 \quad 89.3\end{array}$ treatment using appropriate methods

A5 I am able to undertake bitewing radiographs

$0.0 \quad 10.2$

89.8 
Table 4: Summary of Mean Percentage Scores for Part B

\begin{tabular}{|c|c|c|c|c|}
\hline Item & Question & $\begin{array}{c}\text { No } \\
\text { experience } \\
(\%)\end{array}$ & $\begin{array}{l}\text { Mostly } \\
(\%)\end{array}$ & $\begin{array}{c}\text { Always } \\
(\%)\end{array}$ \\
\hline B25 & $\begin{array}{l}\text { I feel I can manage peoples' expectations of their } \\
\text { treatment }\end{array}$ & 0 & 79.2 & 20.8 \\
\hline B33 & $\begin{array}{l}\text { I am confident to evaluate new dental materials and } \\
\text { products using an evidence-based approach }\end{array}$ & 19.2 & 57.6 & 23.3 \\
\hline B34 & $\begin{array}{l}\text { I am confident to interpret the results of research which } \\
\text { may influence my practice }\end{array}$ & 16.3 & 59.6 & 24.1 \\
\hline B32 & $\begin{array}{l}\text { I have sufficient knowledge of scientific principles } \\
\text { which underpin/support my dental practice }\end{array}$ & 1.6 & 71.0 & 27.3 \\
\hline B42 & $\begin{array}{l}\text { I am able to manage the behaviour of children to } \\
\text { enable appropriate dental treatment }\end{array}$ & 1.2 & 69.8 & 29.0 \\
\hline B41 & $\begin{array}{l}\text { I feel confident managing anxious patients with } \\
\text { appropriate behavioural techniques }\end{array}$ & 3.7 & 64.5 & 31.8 \\
\hline B30 & $\begin{array}{l}\text { I feel confident referring patients with suspected oral } \\
\text { cancer }\end{array}$ & 30.2 & 36.7 & 33.1 \\
\hline B35 & $\begin{array}{l}\text { I use an evidence-informed approach in my clinical } \\
\text { practice. }\end{array}$ & 3.7 & 58.8 & 37.6 \\
\hline B49 & $\begin{array}{l}\text { I feel able to raise concerns about inappropriate } \\
\text { behaviour of my colleagues }\end{array}$ & 10.6 & 48.6 & 40.8 \\
\hline B26 & $\begin{array}{l}\text { I feel able to motivate my patients to encourage self- } \\
\text { care for their dental needs }\end{array}$ & 0.4 & 58.0 & 41.6 \\
\hline B45 & $\begin{array}{l}\text { I am able to work within the constraints of clinical } \\
\text { appointment schedules }\end{array}$ & 0.8 & 57.6 & 41.6 \\
\hline B44 & I maintain accurate records of my clinical notes & 0.0 & 48.8 & 51.2 \\
\hline B43 & $\begin{array}{l}\text { I am able to fulfil my responsibilities as an effective } \\
\text { member of the dental team }\end{array}$ & 0.0 & 46.9 & 53.1 \\
\hline B38 & $\begin{array}{l}\text { I feel confident to address barriers for effective } \\
\text { communication with patients appropriately }\end{array}$ & 2.0 & 44.1 & 53.9 \\
\hline B31 & $\begin{array}{l}\text { I reflect on my clinical practice in order to address my } \\
\text { learning needs }\end{array}$ & 0.4 & 44.3 & 55.3 \\
\hline
\end{tabular}




\begin{tabular}{|c|c|c|c|c|}
\hline B36 & $\begin{array}{l}\text { I feel I can manage to communicate effectively with my } \\
\text { patients }\end{array}$ & 0.0 & 42.2 & 57.8 \\
\hline B29 & $\begin{array}{l}\text { I am able to refer patients with complex treatment } \\
\text { needs appropriately }\end{array}$ & 2.0 & 40.0 & 58.0 \\
\hline B39 & $\begin{array}{l}\text { I feel confident to communicate potential risks of } \\
\text { operative procedures to patients }\end{array}$ & 0.8 & 41.0 & 58.2 \\
\hline B28 & $\begin{array}{l}\text { I feel comfortable asking for help from supervisor or } \\
\text { colleague if needed }\end{array}$ & 0.0 & 41.4 & 58.6 \\
\hline B27 & I recognise my personal limitations in clinical practice & 0.8 & 39.6 & 59.6 \\
\hline B37 & $\begin{array}{l}\text { I provide opportunities for my patients to express their } \\
\text { expectations from dental treatment }\end{array}$ & 0.4 & 39.8 & 59.8 \\
\hline B46 & $\begin{array}{l}\text { I take responsibility for my continuing professional } \\
\text { development }\end{array}$ & 0.8 & 38.8 & 60.4 \\
\hline B50 & $\begin{array}{l}\text { I take appropriate measures to protect patient } \\
\text { confidentiality }\end{array}$ & 0.4 & 38.4 & 61.2 \\
\hline B48 & $\begin{array}{l}\text { I restrict my relations with my patients to a professional } \\
\text { level }\end{array}$ & 1.2 & 32.7 & 66.1 \\
\hline B47 & $\begin{array}{l}\text { I am aware of my legal responsibilities as a dental } \\
\text { professional }\end{array}$ & 0.4 & 31.4 & 68.2 \\
\hline B40 & $\begin{array}{l}\text { I feel confident to communicate appropriately with my } \\
\text { colleagues }\end{array}$ & 0.0 & 30.7 & 69.3 \\
\hline
\end{tabular}

